\title{
THE REPRESENTATION OF WOMEN IN THE JUDICIAL BRANCH: EIGHTEEN LATIN AMERICAN HIGH COURTS IN COMPARATIVE PERSPECTIVE
}

\author{
La representación de mujeres en el poder judicial: \\ dieciocho altas cortes de América Latina en \\ perspectiva comparada
}

\author{
SANTIAGO BASABE SERRANO \\ FLACSO-Ecuador \\ sbasabe@flacso.edu.ec
}

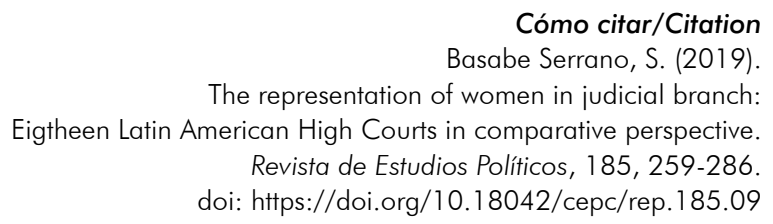

\begin{abstract}
This article explores the representation of women in the high courts of eighteen Latin American countries. Using an unpublished database, we find that, as in the legislatures and ministerial cabinets, the number of women in high courts is small. The article also demonstrates that although there is little difference in judges' ages or postgraduate studies, men reach the high court levels more easily. Additionally, empirical evidence shows that, at the time of their appointment, the percentage of women with prior judicial experience is usually greater than for men. These results show that the greater presence of male judges is related not to academic merit or previous judicial experience but rather to a structural process of exclusion of women from political decision-making fields. In this regard, the article also finds that the few positions assigned to female judges are not in areas of great political significance, much less in the presidency of the high courts.
\end{abstract}

\section{Keywords}

Women; high courts; Latin American; judicial representation; comparative politics. 


\section{Resumen}

Este artículo explora la representación descriptiva de mujeres en las altas cortes de dieciocho países de América Latina. A partir de una base de datos inédita, este artículo evidencia que al igual que en legislaturas y gabinetes ministeriales, el número de mujeres en las altas cortes también es reducido. Este artículo también demuestra que, si bien hay poca diferencia en la edad de los jueces o en los estudios de posgrado, los hombres llegan a los tribunales superiores con mayor facilidad. Adicionalmente, la evidencia empírica constata que el porcentaje de mujeres con experiencia previa en la rama judicial es más alto que la de los hombres. Estos hallazgos permiten observar que la presencia mayoritaria de los hombres en las altas cortes no está relacionada con el mérito académico o con la experiencia previa dentro de las judicaturas, sino más bien con un proceso estructural de exclusión de las mujeres de los diferentes campos de toma de decisión política. En este sentido, este artículo también demuestra que las pocas posiciones asignadas a las mujeres juezas no se encuentran en áreas consideradas de mayor importancia política y mucho menos en la presidencia de las altas cortes.

\section{Palabras clave}

Mujeres; altas cortes; América Latina; representación judicial; política comparada. 


\section{CONTENTS}

I. INTRODUCTION. II. THE POLITICAL REPRESENTATION OF WOMEN IN PUBLIC DECISION-MAKING ARENAS. III. WOMEN IN LATIN AMERICAN HIGH COURTS. IV. POLITICAL IMPACT OF THE ISSUES ASSIGNED TO FEMALE JUDGES. V. CONCLUSIONS AND RESEARCH AGENDA. BIBLIOGRAPHY. APPENDIX.

\section{INTRODUCTION}

Although studies of the representation of Latin American women in legislatures and ministerial cabinets have increased in recent years, research that analyzes the prevalence of female supreme or constitutional judges is still scarce. This neglect is noteworthy because the courts are decision-making arenas in which the most significant public policies are either upheld or changed. Additionally, courts (especially constitutional courts) are a decisive arena in which to position diverse, gender-related demands and, more generally, the demands of traditionally excluded or discriminated groups. For these reasons, analyzing the performance of judges in high courts is critical to evaluating the evolution of the inequalities found in different Latin American countries.

Additionally, the study of the presence of women in high courts is interesting because unlike other arenas of political decision-making, the institutional mechanisms of positive or reverse discrimination are practically nonexistent (Bensouda, 2014; Durbach y Chappell, 2014; Grey, 2014; Ní Aoláin, 2014; Scribner y Lambert, 2010; Hoekstra, 2010). In fact, Htun and Piscopo (2014) have shown that while legislatures have made considerable progress in establishing quota laws, there are no proposals of this type in the judicial arena. Except for general statements such as one made by former President Kirchner by means of an Executive Decree that the appointment of Argentine Supreme Court justices should attempt to reflect gender differences, in the majority of the region's countries there are no legal provisions to reduce inequalities in the representation of men and women in high courts ${ }^{1}$.

1 With Decree No. 222, former President Néstor Kirchner established a new selection process for Argentina's Supreme Court justices. This institutional design established that the appointments should strive for diversity of gender, specialty and regional origin. 
Ecuador is an exception because in the institutional design for the selection of judges for it most recent National Court, Judicature Council established positive discrimination policies for women. For example, additional points were given to female candidates and, in the event of a tie between a male and a female applicant during the selection process the regulation established the position should be assigned to the woman. As a result of this institutional design, Ecuador's National Court had 45\% women in 2017 and, along with Guatemala (53.8\%) and Venezuela (50\%), had Latin America's highest representation of female judges in the high courts.

Moreover, the scarcity of scientific research regarding women's access to the judiciary branch has led to a situation where studies that explore more substantive issues (such as the types of issues assigned to judges) are even more difficult to find (Basabe-Serrano, 2017). Therefore, to address these obvious gaps, this article explores various dimensions of the representation of women in the high courts of 18 Latin American countries. Some of the research questions I propose include the following: (i) To what extent does the representation of female judges follow trends such as those observed in legislatures and ministerial cabinets? (ii) To what extent does the representation of female judges vary between countries? (iii) What types of issues are prioritized for resolution by female judges?

This article has four sections. In the first section, I discuss the status of the literature focused on the study of the political representation of women in public decision-making arenas. In the second section, I compare the representation of women in legislatures and ministerial cabinets to their representation in courts. Additionally, I empirically describe some variables related to the educational level, age groups and previous judicial experience of judges in high courts. In the third section, I analyze the inherent discrimination within the courts based on observation of the political significance of the issues assigned to women. Finally, in the fourth section, I present conclusions and thoughts for future research.

\section{THE POLITICAL REPRESENTATION OF WOMEN IN PUBLIC DECISION-MAKING ARENAS}

One of the fundamental goals of studies of women and politics has been the identification of variables that explain their unequal representation and participation in various public arenas, primarily legislatures and ministerial cabinets (Mansbridge et al., 2010; Marion, 2007; Welzel et al., 2002; Mansbridge, 1994, 1990a, 1990b; Phillips, 1991; Pateman, 1970). For example, there are studies that pointing out that an increase in the number of women 
with skills, abilities and professional expertise is pressuring the political marketplace for women's inclusion in the different areas of public decision-making (Bego, 2014; Sainsbury, 2004; True and Mintrom, 2001; Studlar and Moncrief, 1997; Davis, 1997; Norris and Lovenduski, 1995; Norris, 1987). This conjecture is based on the assumption that the labor market is not distorted; therefore, the inclusion of women in the political arena is essentially an issue of merit and capabilities.

Nonetheless, Matland (1998) showed greater access to education and female participation in the economy-related aspects of life have a positive influence on the representation of women in legislatures of industrialized countries (Fallon et al., 2008) ${ }^{2}$. In this regard, Inglehart and Norris (2003) argue that cultural variables related to the role historically attributed to women explain the lower representation of women in the political arenas of some countries although their academic achievement is greater than that of men $^{3}$. In Latin America, Escobar-Lemmon and Taylor-Robinson (2005) have reported that the increase in the female workforce is not an influential factor in the access of women to ministerial cabinets, while greater access to education is a significant, but negative, variable ${ }^{4}$. Htun and Piscopo (2014) present a similar argument when demonstrating that the presence of structural variables by themselves does not explain the discrepancies in the presence of women in Latin American legislatures.

Among the research focusing in the mentioned variables some arguing that the increase in women in certain arenas of political decision-making engenders a similar effect in other public arenas (Krook and O'Brien, 2012; Whitford et al., 2007; Escobar-Lemmon and Taylor-Robinson, 2005; Sainsbury, 2004; Davis, 1997; Skjeie, 1991)5. Consequently, the proliferation of women in key positions would inform the labor market regarding the

2 However, when studying ministerial cabinets of Latin American presidencies, Htun (2003) found a positive relationship between the increase in female ministers and their professional training.

3 Whitford et al. (2007) report that increases in the female labor force improve access to public office, but only at the level of vice ministries, even in industrialized countries.

4 In their study of 117 countries, Hook and O'Brien (2012) arrive at conclusions similar to those of Escobar-Lemmon and Taylor-Robinson (2005) regarding the lack of significance of the female labor force variable on the degree of representation of women in ministerial cabinets.

5 However, the findings of Jalalzai (2014) partially confirm the validity of this hypothesis. This author indicates that the increase in female legislators in Europe during the 1990s only affected the number of female prime ministers and presidents in the following decade. 
advisability of increasing female representation in the political arena. However, this causal link has also revealed negative findings, primarily in the research related to the representation of women in ministerial cabinets (Fleischer and Seyfried, 2015; Kobayashi, 2004; Rodríguez, 2003).

Further, a considerable body of research indicates there are variables related to the characteristics of the "demand", regarding who should assign positions in the different public decision-making arenas and the current political and institutional context, both of which affect the representation of women in the political arena (Kunovich and Paxton, 2005). For example, studies of ministerial cabinets mention that to the extent that presidents lean ideologically to the left, the probability of appointing female ministers increases ( $i b i d$.). Although the empirical evidence for the validity of this conjecture is found primarily in industrialized countries, positive findings are also reported for Latin America (Escobar-Lemmon and Taylor-Robinson, 2005; Siaroff, 2000; Studlar and Moncrief, 1999; Davis, 1997; Norris 1997, 1987; Lovenduski and Norris, 1993) 6 .

However, other research mentions that in recent years, both centrist and right-wing parties have also included women in ministerial cabinets; thus, the explanatory capacity of that variable has been declining (Caul, 2001; Studlar and Matland, 1996; Matland and Studlar, 1996; Skjeie, 1991). Additionally, this criticism strengthens in Latin American countries where left-right boundaries in the economic sphere do not necessarily align with liberal-conservative boundaries with respect to value-related beliefs concerning how society should be organized and the role that women should occupy in handling political affairs. Htun (2003) and Baldéz (2002) find an empirical complement to these objections when demonstrating that the ideological positions of presidents do not affect the degree of female representation in Latin American ministries.

The specialized literature on this topic has also argued that the existence of a smaller ruling legislative caucus would negatively affect the increase in women in ministerial cabinets (Reynolds, 1999). The causal link would be given by a nested chain of events would follow this sequence. First, if the president has little legislative support, she will need to establish government coalitions with other political parties. As a result, ministerial posts would be part of those agreements. Given that the main actors in political parties are men, there is a high probability that they will want to occupy the ministerial posts

6 Based on 117 countries studied, Krook and O’Brien (2012) also reports the existence of a significant causal link between a president's left-leaning ideology and an increase in women in ministerial cabinets. 
(Amorin Neto, 2002) ${ }^{7}$. However, if a president has a legislative majority, there is less need to establish government coalitions, and therefore, the Executive would have more freedom to appoint women to his or her ministerial cabinet.

Although this argument is plausible, several anomalies observed in Latin America must be highlighted. Although presidents with majority legislative caucuses are the exception and therefore have a greater need to form additional government coalitions what usually happens in the region is that presidents only develop legislative coalitions to pass laws (García Montero, 2007). Therefore, except for Chile and Brazil, even when presidents are weakly positioned in the legislatures, the formation of government coalitions is usually the exception. Therefore, the size of the legislative coalition would be irrelevant to the study of the representation of women in ministerial cabinets. Escobar-Lemmon and Taylor-Robinson (2005) empirically demonstrate this when reporting that this variable is not significant when assessing the presence of female ministers in Latin America.

Others research have indicated party competition in the legislature favors the appointment of women to ministerial cabinets (Heppell, 2012). The work done in industrialized democracies indicates that in an environment of high partisan competition, governments would have enough incentives to place women in ministerial cabinets, as this would increase the capture of women's votes (Studlar and Moncrief, 1997; Davis, 1997). However, in the case of Latin America and despite the considerable partisan competition in the majority of the countries, Escobar-Lemmon and Taylor-Robinson (2005) have shown that this variable is not significant when analyzing the inclusion of women in ministerial cabinets ${ }^{8}$.

Regarding the influence quota laws and other electoral system rules can exert to increase the number of female legislators, various studies have exposed the explanatory potential of these factors for understanding improvements in women's access to these political decision-making arenas (Jones et al., 2012; Jones, 2009, 2004; Htun and Jones, 2001). However, these types of variables are irrelevant when studying ministerial cabinets or courts, not only because their members are not elected by popular vote but also because of the lack of laws that enable affirmative action mechanisms. The provisions for affirmative

7 Krook and O'Brien (ibid.) report that the size of the ruling party influences the appointment of women in ministerial cabinets in only $20 \%$ of the countries in their analysis.

8 Krook and O'Brien's research (2012) of women in ministerial cabinets worldwide substantiates the significance of partisan competition in only $20 \%$ of the countries analyzed. 
action mechanisms to form the National Court of Ecuador constitute a notable exception.

Finally, some authors have indicated that emblematic events arising in a national or international context can become a "trigger" with far-reaching effects on both political actors and the electorate regarding including more women in various political decision-making arenas. Therefore, it is argued that after the emblematic event occurs, inequalities in representation will decrease over time. Some of the events most cited in the topical literature are the appointment of the first women in decision-making positions such as the legislature or the presidency, and ideas from international organizations on diminishing the unequal representation of men and women in public spaces (Sainsbury, 2004; Rodriguez, 2003; Russell and DeLancey, 2002; Caul, 2001; Htun and Jones, 2001; True and Mintrom, 2001; Studlar and Moncrief, 1997; Davis, 1997)9. The causal link between the ideas generated in the national and international environment and the increase in women in ministerial cabinets has been verified empirically in a large number of papers (Escobar-Lemmon and Taylor-Robinson, 2005; Rodríguez, 2003; True and Mintrom, 2001; Htun and Jones, 2001). However, Krook and O'Brien's research (2012) in 117 countries found that the passage of time, whether from the first declarations by international organizations in favor of increasing the number of women in politics or from the appointment of the first female legislator, has little capacity to explain the increase in female ministers. Similarly, Escobar-Lemmon and Taylor-Robinson (2005) also found no causal relationship between this variable and the increase in women in Latin American ministerial cabinets.

Regarding the presence of women in the judicial branch, the research mainly focuses on the analysis of the dimensions related to descriptive or substantive representation. On the one hand, some researches study how do international courts decide on cases about women's rights (Bensouda, 2014; Durbach and Chappell, 2014; Grey, 2014; Ní Aoláin, 2014). On the other hand, there are researches in which the use of gender-neutral language is analyzed as a topic for analysis in judicial decisions (Oosterverld, 2014; Koomen, 2014; Kenney, 2010; Maveety, 2010). Besides, there are vital contributions that examine to what extent a court decision is influenced by the fact that an attorney is a man or a woman (Szmer et al., 2010). Researches of constitutionalism have also

9 The majority of the annotated research arguing that such events have resulted in an increased number of appointments of women to ministerial cabinets points to the Convention on the Elimination of All Forms of Discrimination against Women (1979) or the Fourth World Conference on Women (Beijing, 1995). 
explored how the inclusion of gender-oriented provisions affecting the political and economic status of women (Scribner y Lambert, 2010).

Regarding the possibility of extending the legislative quotas rules to the courts, there is research that proposes that this could be a solution to the under-representation of women in the judicial branch (Hoekstra, 2010). There have been some attempts of institutional reforms in countries as different as India, Ecuador, England, and South Africa. The discussion has not only been at the national level, but even the International Criminal Court discusses the viability of this type of measures (Hoekstra, 2010; Malleson, 2009). However, the cited works concentrate on observing the effect of the quota rules, ignoring the explanatory capacity of other variables attributable to the political environment, to the skills of the judges or even to other facts of the institutional design of courts.

From a perspective focused on the study of the behavior of women judges, studies for the United States have essential advances (Williams, 2007; Hurwitz and Lanier, 2003; Bratton and Spill, 2002; Alozie, 1996). However, these studies do not seek to explain the factors that influence the arrival of judges but rather their performance once they are in the benches. In terms of the access of women to the judicial branch, some works describe the representation of women in high courts, although they do not deepen on the reasons that would explain this phenomenon (Cowan, 2006; Malleson, 2003; Kenney, 2002). Reid's research could also be framed within these characteristics $(2010,2004)$ in which she shows that the courts of appeals in the United States in which judges are elected through popular election, women candidates have disadvantages of diverse types compared to their colleagues.

One of the few studies that try to explain the sub representation of women in courts of justice is the one proposed by Williams and Thames (2008). This research explores the variables that would affect the presence of judges in high courts of countries that are part of the Organization for Economic Cooperation and Development (OECD) between 2006 and 2007. In conceptual terms, Williams and Thames (2008) point out that the prestige of the court, the mechanisms of selection and the importance that each country grants to the political participation of women affect the presence of judges in high courts. Empirically, the authors draw on two negatives through which they find that: (i) the higher number of benches in the courts increases the probabilities of access by judges; (ii) the presence of quota rules positively affects the arrival of women to the courts; and, (iii) as more time has elapsed since the women's suffrage, the chances of observing more judges in high courts are increased.

A review of the literature on this topic enables to derive at least two conclusions. First, studies of women and politics in Latin America lack convincing 
empirical findings regarding the variables that describe and explain the under-representation of female legislators and ministers (Basabe-Serrano, 2017). Second, research of the presence of women in high courts is practically nonexistent ${ }^{10}$. Therefore, in the following section, I will empirically explore some key variables for understanding the representation of female judges in the supreme and constitutional courts of Latin America. Towards the end of this section, I present conjectures that could serve as a starting point for additional causal studies.

\section{WOMEN IN LATIN AMERICAN HIGH COURTS}

In this section, I will compare the descriptive representation of female supreme and constitutional judges in Latin America with that of female legislators and ministers. Subsequently, I will focus on the discussion of different aspects of women in high courts for 18 countries in the region ${ }^{11}$. For the empirical work, I created a database with information obtained from official web pages, files and resumes (see Appendix 1 for descriptive statistics). The database includes the judges in office of both supreme courts and constitutional courts during the first quarter of $2017^{12}$. Of the 324 judges $(n=324)$ in the database, $69.44 \%$ (225) are men and $30.56 \%$ (99) are women. This preliminary empirical observation is critical because it is the starting point for the subsequent analysis of the unequal representation of women not only in high courts but also in all political decision-making arenas.

When comparing the representation of women in supreme and constitutional courts with their representation in legislatures and ministerial cabinets, the differences are minimal. The average of female judges is $28.66 \%$, while the average of female legislators is $26.83 \%$ and female ministers is $24.8 \%$. However, when comparing the percentage of female judges to female legislators and ministers by country, the results vary. The proportion of female judges to female legislators is $50 \%$ to $14 \%$ in Guatemala and Venezuela and $33 \%$ to $15 \%$ in Paraguay, revealing a clear disproportion. The opposite is true

10 A notable exception is the work of Shen (2017), although it focuses on understanding the public and private lives of judges in China.

11 The supreme courts included are from Argentina, Bolivia, Brazil, Chile, Colombia, Costa Rica, the Dominican Republic, Ecuador, El Salvador, Guatemala, Honduras, Mexico, Nicaragua, Panamá, Paraguay, Peru, Uruguay and Venezuela. The constitutional courts and tribunals included are from Guatemala, Ecuador, Bolivia, the Dominican Republic, Chile, Peru and Colombia.

12 Excluded from the database are temporary, interim and substitute judges. 
for Mexico (18.2\% to $42 \%$ ), Bolivia (31.3\% to $53 \%$ ), Argentina (20\% to $36 \%)$ and Peru (15.4\% to $28 \%)$. In these countries, the percentage of female legislators far exceeds that of female judges. In the remaining countries analyzed, the percentage difference between female judges and legislators is less than $10 \%^{13}$.

When comparing the representation of women in high courts to that in ministerial cabinets, the percentage of female judges is clearly higher than that of female ministers in Guatemala (50\% to $11.8 \%$ ), Venezuela (50\% to $16.3 \%$ ), Ecuador $(51.7 \%$ to $27.8 \%)$, Honduras $(33.3 \%$ to $11.1 \%)$ and, to a lesser extent, El Salvador (33.3\% to $23.1 \%$ ). However, the percentage of female ministers far exceeds that of female judges in Nicaragua (33.3\% to $57.1 \%)$, Chile (23.3\% to $39.1 \%$ ), Colombia ( $16.1 \%$ to $29.4 \%$ ), Panama ( $11.1 \%$ to $23.5 \%)$ and Peru (15.4\% to $27.4 \%)$. Furthermore, the difference between percentage of female ministers and judges is less than $10 \%$ in Costa Rica, Paraguay, Bolivia, the Dominican Republic, Argentina and Mexico. Finally, the percentages of women in high courts and in ministerial cabinets are similar in Uruguay $(20 \%)$ and Brazil $(18.2 \%)^{14}$. Figure 1 illustrates the description provided above.

The empirical evidence presented above reveals a profoundly unequal region in terms of women's access to the three branches of government. From this premise, I will next compare the Latin American countries in terms of female judge representation and whether they serve in supreme or constitutional courts. Additionally, I will discuss the behavior of variables for the educational level and age of the members of Latin American high courts. This analysis examines the differences between judges from the same country and differences between judges from different countries. This will enable us to observe whether the inequalities observed in the representation of female judges with respect to female legislators and ministers are seen in the internal workings of the judicial branch.

Regarding the descriptive representation of women in supreme and constitutional courts, Figure 2 illustrates three clearly differentiated analytical

13 The percentage of female judges is higher than that of legislators for Ecuador $(51.7 \%$ to $42 \%)$, Brazil $(18.2 \%$ to $10 \%)$, Honduras $(33.3 \%$ to $26 \%)$, Chile $(23.3 \%$ to $16 \%)$, Uruguay (20\% to $16 \%$ ) and El Salvador (33.3\% to $32 \%)$. The opposite is true for Nicaragua $(33.3 \%$ to $41 \%)$, Panama (11.1\% to $18 \%)$, Colombia $(16.1 \%$ to $20 \%)$ and the Dominican Republic $(24.1 \%$ to $27 \%)$.

14 The percentage of female judges compared to female ministers is higher in Paraguay (33.3\% to $25 \%$ ), the Dominican Republic (24.1\% to $16.7 \%)$, Mexico (18.2\% to $13.6 \%$ ), Bolivia (31.3\% to $29.2 \%$ ) and Argentina (20\% to $19 \%)$. In Costa Rica, there are more women in ministerial cabinets than in high courts (33.3\% to $38.1 \%)$. 
Figure 1. Females as judges in high courts, legislators and ministers in Latin America (2017)

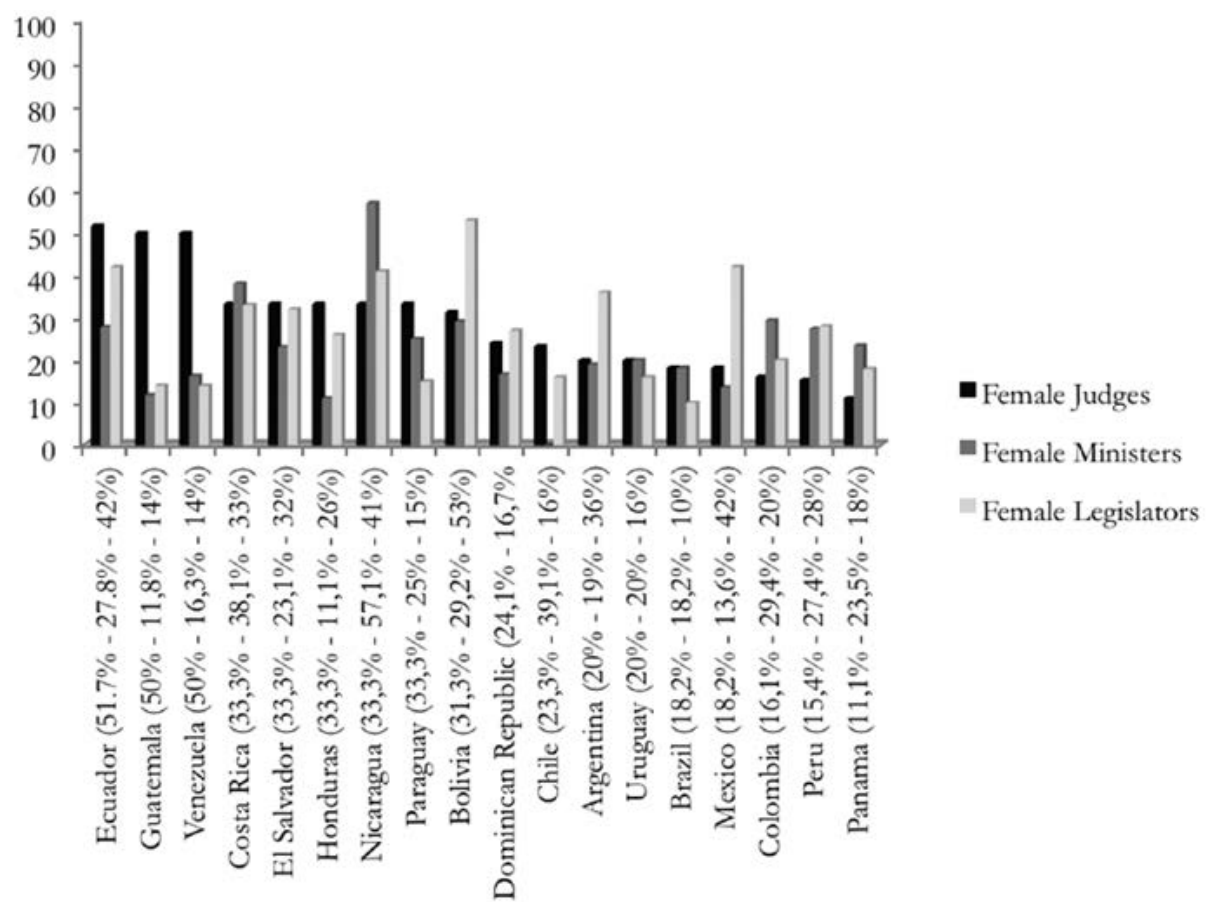

Source: Official websites of Latin American supreme and constitutional courts.

categories. In the first category are those countries that are equal in the number of men and women serving in their high courts (black bars). In this category are Ecuador (51.7\%), Guatemala (50\%) and Venezuela (50\%). Ecuador is the most notable of the three because the percentage of women is higher than that of men in that country. It is striking that a country as Venezuela, with low performance in many dimensions of the democracy, shows a judicial branch with equality in the representation of women and men in it high court.

The second category includes countries in which only one third $(33.33 \%)$ of the members of the high courts are women (gray bars). In this category are Costa Rica, El Salvador, Honduras, Nicaragua and Paraguay. I will also include Bolivia in this category because its somewhat lower representation of female judges $(31.3 \%)$ is marginally different that of the other five countries. The third category is composed of countries in which less than $25 \%$ of the high court judges are women. This category is striking not only because it represents an intense inequality but also because half of the countries studied are in this category. In this category are the Dominican Republic (24.1\%), Chile 
(23.3\%), Argentina (20\%), Uruguay (20\%), Brazil (18.2\%), Mexico (18.2\%), Colombia (16.1\%), Peru (15.4\%) and Panama (11.1\%).

Figure 2. Women in Latin American supreme and constitutional courts (2017)

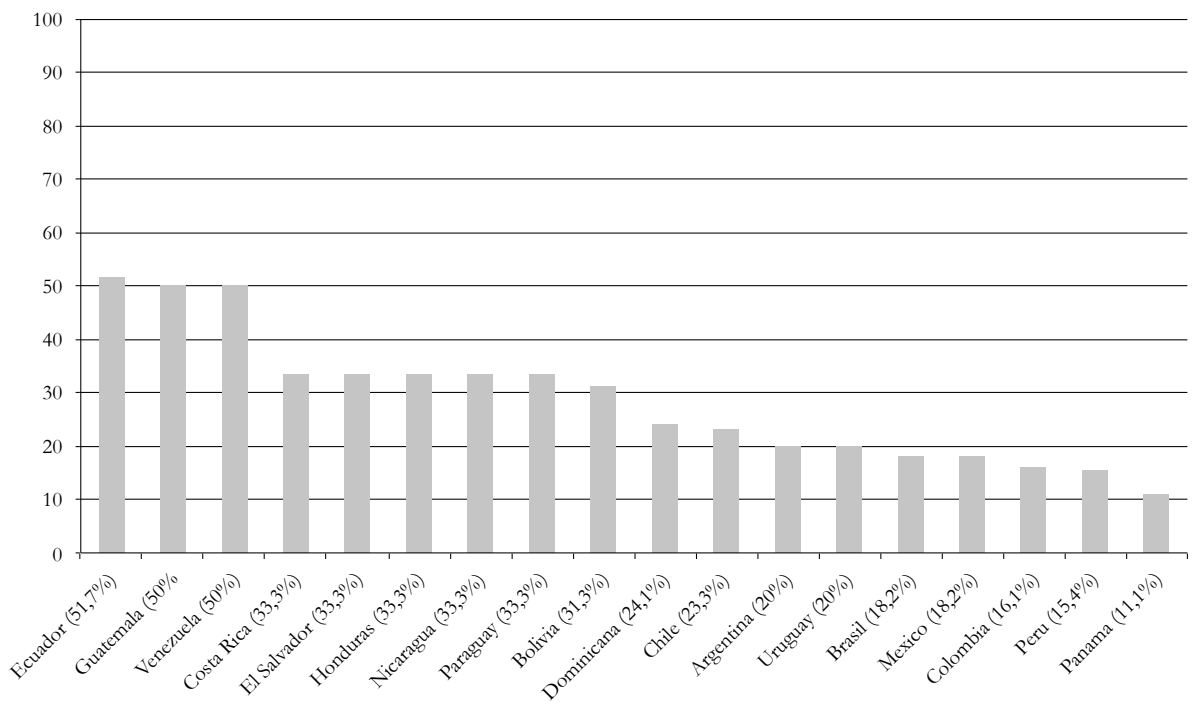

Source: Official websites of Latin American supreme and constitutional courts.

In another vein, I will now explore and assess whether the aforementioned unequal representation of women has different patterns depending on the ordinary or constitutional jurisdiction of the courts. For this purpose, I only considered the seven countries that have separate ordinary and constitutional courts. Intuitively, one might believe that there would be fewer female constitutional judges, given the historical exclusion of women and the increasingly preeminent political space occupied by this political decision-making arena. However, the data do not support this conjecture because the differences are minimal. In fact, $30.71 \%$ of supreme court justices are women ( 82 of 267 benches), while $30 \%$ of constitutional court justices are women (18 of 60 benches).

When making the comparison described above within each of the seven countries analyzed, the differences are not obvious, although two patterns of behavior can be identified. First, in Bolivia, the Dominican Republic, Chile, Peru and Colombia, the difference between men and women in supreme and constitutional courts is less than $10 \%$. Except in the case of Colombia, the presence of women is usually slightly higher in supreme courts than in constitutional courts. Second, there is greater inequality in Guatemala and Ecuador 
among supreme and constitutional judges. In Guatemala, the representation of female judges in the constitutional court $(40 \%)$ is lower than that observed in the supreme court $(53.8 \%)$, while the opposite occurs in Ecuador, with a greater presence of women in the constitutional court $(66.7 \%)$ than in the national court (45\%). Figure 3 illustrates this analysis.

Figure 3. Comparison of women in Latin American supreme and constitutional courts (2017)

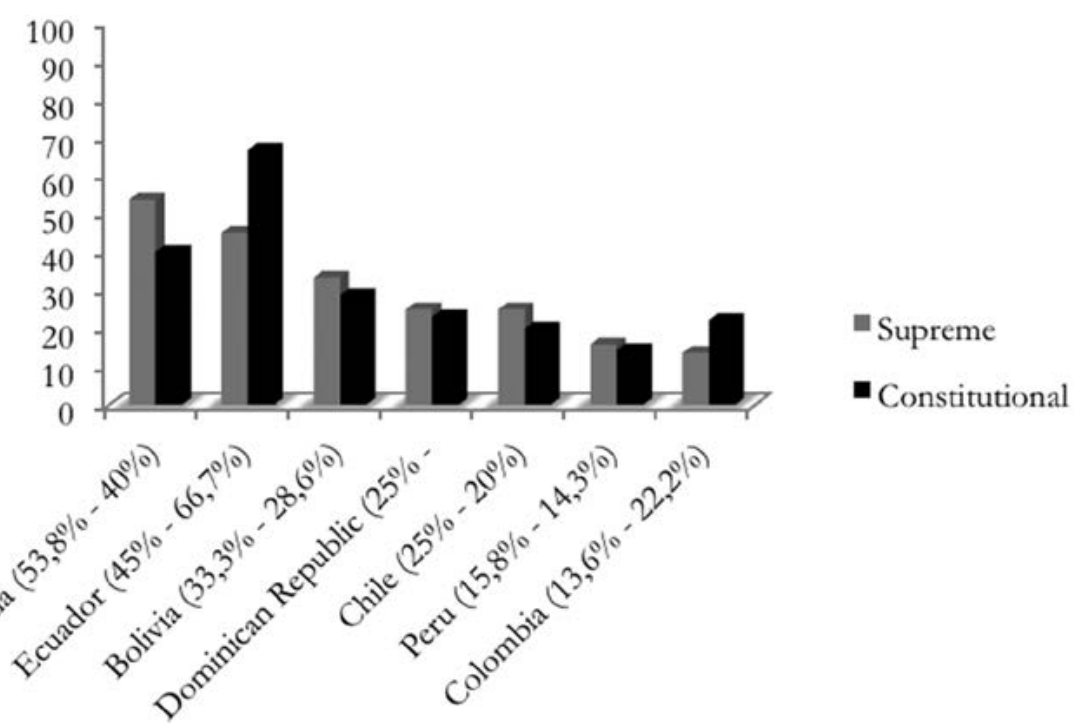

Source: Created by the author from the official websites of Latin American supreme and constitutional courts.

In similar way with research in legislatures and minister cabinets, I would expect that judges who will adjudicate at the highest judicial or constitutional levels have formal education beyond a law degree to complement their professional skills. In relation with educational level attained, $45.98 \%$ of male judges and $50.5 \%$ of female judges do not have postgraduate studies. This data point is noteworthy because it would be expected that people who will adjudicate at the highest judicial or constitutional levels have formal education beyond a law degree to complement their professional skills. In terms of master's degrees, the percentage of women who earned this degree slightly exceeds that of men ( $32.32 \%$ to $31.69 \%$, respectively). This proportion is reversed, although not significantly, when analyzing those who hold doctoral degrees. In this case, the percentage of men $(22.32 \%)$ with this degree exceeds that of women $(17.17 \%)$. 
As Appendix 2 shows there is not correlation between sex and academic training. This result is the basis for arguing while there are more men in Latin American high courts, this is not because their academic training is better than that of women, at least with respect to the university degrees they have earned. In addition, when I compare the postgraduate degrees of men and women, clear differences are observed, although this correlates to the unequal representation of one or the other in the courts analyzed. Fewer women earn master's degrees than men $(31.37 \%$ to $68.63 \%)$, while the gap becomes even wider regarding doctoral degrees $(25.37 \%$ to $74.63 \%)$. If the exclusionary nature of women's historical role and the associated time-related obstacles to pursuing academic activities such as completing postgraduate studies are considered, there would be an explanation for the empirical evidence reported. Motherhood could also be a variable that is present in these cases, one that hinders the completion of postgraduate studies in general and doctoral studies in particular (Pateman, 1970).

Furthermore, regardless of gender, there are no judges with doctorates in five countries (Bolivia, Honduras, Nicaragua, Panama and Uruguay), while in several high courts no woman holds this academic degree (Chile, Colombia and Ecuador). Additionally, in Argentina, Brazil, Mexico, Peru and Venezuela, there is a notable inequality among judges who have a doctorate. However, Guatemala, Paraguay and Costa Rica have smaller gaps between men and

Figure 4. Female judges with doctorates in supreme and constitutional courts
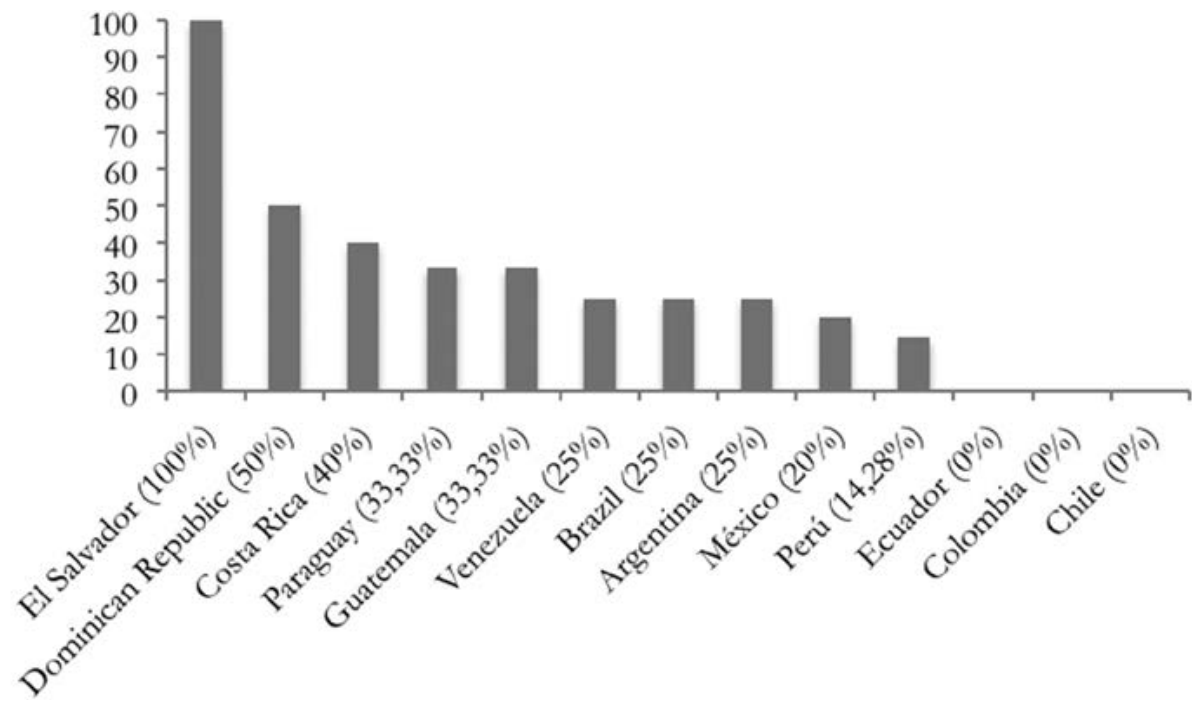

Source: Created by the author based on information from the official web sites of Latin American supreme and constitutional courts. 
women with this academic degree. Finally, there is parity in the number of male and female judges with a doctorate in the Dominican Republic, while in El Salvador the only judge with that degree is a woman. Figure 4 illustrates this discussion.

Regarding the judges' ages, the average is 60.03 years for men and 57.96 years for women. This relatively small difference presents some anomalies for the analysis once the data are disaggregated by categories. When the youngest judges (50 years or less) are considered, the empirical evidence shows that there are more women than men $(25.31 \%$ to $15.42 \%)$ in this age range. This finding is noteworthy because it would be expected that, due to the Latin America's inequalities, women would need to obtain more professional experience than men to reach the highest judiciary in their countries. Intuitively, because professional experience is acquired over time, women should reach the highest judiciary at a later age than men; however, this does not occur.

Within the age ranges of 51 to 60 years and 61 to 70 years, the differences between men and women are minimal $(37.23 \%$ to $35.44 \%$ and $32.97 \%$ to $30.37 \%$, respectively), so this does not merit further analysis. Regarding those 70 or more years of age, the empirical evidence presented reveals that there are more men than women in this range ( $14.36 \%$ to $8.86 \%)$. Therefore, when all empirical evidence related to the age of high-court judges is considered together, we can state there is higher percentage of women among the youngest judges, while there are more men among the oldest judges. Figure 5 illustrates the age variable for males and females working in the high courts of Latin America.

Figure 5. Supreme and constitutional court judges, by age.

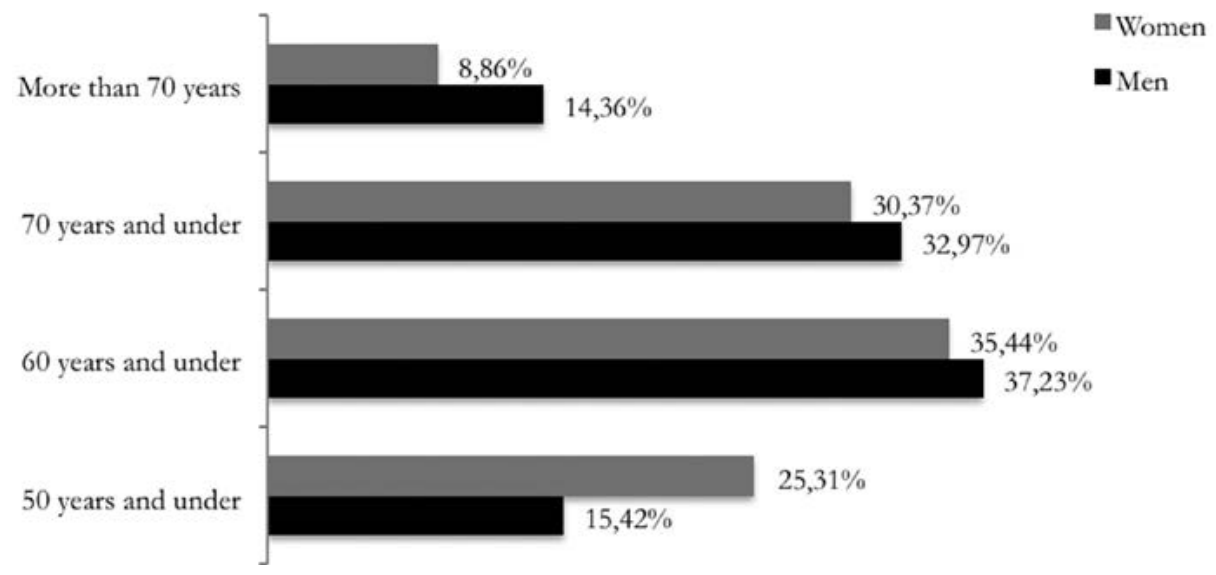


Source: Created by the author based on information from the official web sites of Latin American supreme and constitutional courts.

To examine the previous judicial experience of judges, I quantified the number of years in positions related to the judicial branch or the prosecutor's office prior to their appointment ${ }^{15}$. In general terms, the first finding is that nearly two thirds of the men and women who reach the high courts of Latin America have prior experience in either the judicial branch itself or the prosecution (63.02\%). This evidence allows asserting the benches in the high courts for independent lawyers or from other public sector fields are limited ${ }^{16}$. On the other hand, if the analysis considering just women judges in high courts with previous judicial experience respect to women without previous judicial experience, the majority is in the first group (66.32\% to $33.68 \%)$. In relation to men judges the results are similar. Men judges with previous judicial experience is $61.58 \%$, and without previous judicial experience is $38,42 \%$.

In this part, I analyzed interaction between previous judicial experience and age. Figure 6 shows that of the total women with previous judicial experience, $6.97 \%$ had more than 30 years of judicial service when they attained positions in high courts, while only $5.88 \%$ of the men in that group had the same amount of experience. A similar finding is revealed when comparing the percentage of women and men who have had 20 to 30 years of previous judicial experience. In this case, I found $9.30 \%$ of female judges and $8.82 \%$ of male judges had this level of experience. However, when analyzing groups of judges with 11 to 20 years of judicial experience, the data are somewhat reversed. In this case, the percentage of men $(22.05 \%)$ is somewhat higher than that of women $(16.27 \%)$, while in the group of judges with 1 to 10 years of judicial experience, there are more women $(30.23 \%)$ than men $(22.54 \%)$. Overall, the average prior judicial experience of men is 9 years, while that of women is 8.62 years. As was seen in the case of postgraduate studies, these differences are minor, but the gaps in the descriptive representation of female judges are conspicuous.

15 Due to a lack of information, this portion of the analysis excludes judges from Nicaragua.

16 It also allows me to conclude that obtaining a bench in high courts is primarily the result of prior interaction with the dynamics and practices of a traditionally macho and conservative institution, such as the judicial branch of government. 
Figure 6. Previous judicial experience by gender ${ }^{17}$

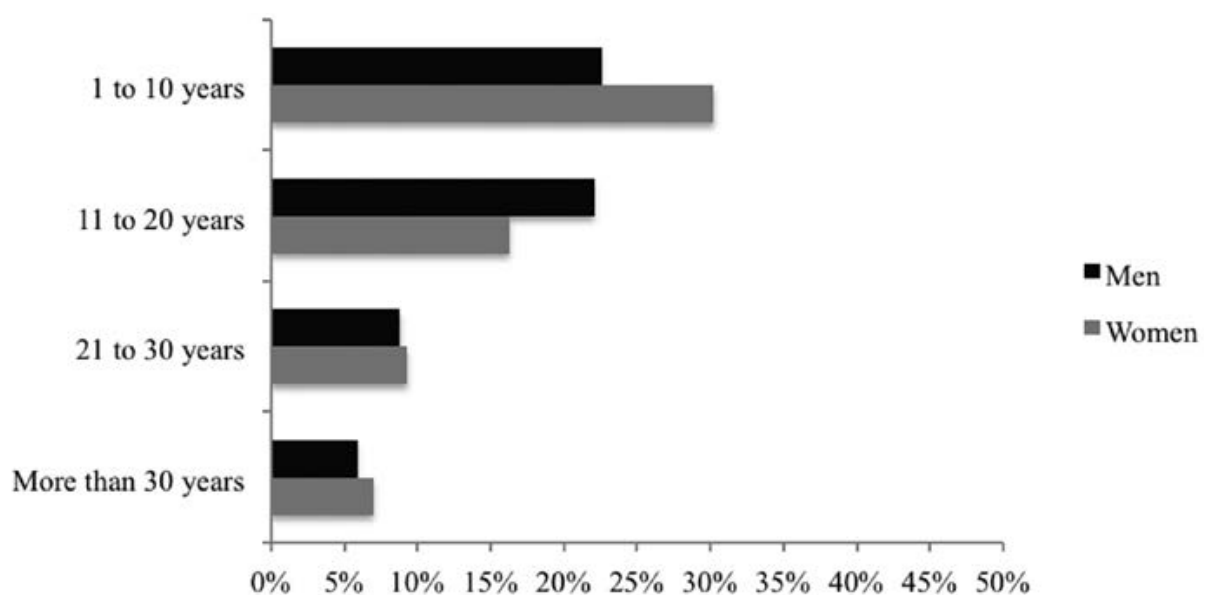

Source: Created by the author based on information from the official websites of Latin American supreme and constitutional courts.

Beyond the important task of providing empirical evidence of both the number of women in supreme and constitutional courts and some difference-making personal attributes with respect to their male colleagues, an additional scientific research challenge is to study the type of activities assigned to female judges in Latin America. Therefore, to assess whether the representation of women in high courts goes beyond mere numbers and involves relinquishing relevant political decision-making responsibilities, in the following section I will evaluate the issues primarily assigned to female judges in Latin America.

\section{POLITICAL IMPACT OF THE ISSUES ASSIGNED TO FEMALE JUDGES}

In this section, I evaluate whether the issues assigned to women in the high courts can be considered as having significant political impact. If the results of this analysis also reveal inequalities, then it could be argued that discrimination is not only numerical in nature but also found in the roles assigned to female judges. When this type of inequality is encountered in studies of

17 Nicaragua was excluded from the analysis, as well as those judges where precise information concerning the number of years of previous judicial experience was not available. A total of 290 judges were considered for this analysis $(n=290)$. 
ministerial cabinets or legislatures, the authors indicate finding a "genderization" of the tasks assigned to men and women (Basabe-Serrano, 2019; Escobar-Lemmon and Taylor-Robinson, 2005; Borner et al., 2009). Therefore, with this antecedent and to study the political impact of the issues assigned to female judges, I used an empirical approach to determine the issues resolved by the specialized tribunals to which they are assigned.

Given that there is not a criterion of political impact of an issue applied to judicial politics, I following the concept offered by Escobar-Lemmon and Taylor-Robinson (2005) and used in other research related with ministerial cabinets (Basabe-Serrano, 2019). I define the political impact of an issue submitted for legal decision to be the level of attention it generates in the public opinion, the media, the political parties and the political system in general. Using this criterion, I developed a variable with two analytical categories. In the first category, called "issues with higher political impact," I placed those courts with specialized chambers that resolve criminal and constitutional issues ${ }^{18}$. In the second category, called "issues with lower political impact," I included courts with specialized chambers that resolve civil and labor issues. I also added other issues to this second category that are only found in a few courts, such as tax, administrative or electoral issues.

Based on these methodological decisions, I excluded from analysis any courts that do not have specialized chambers. This is true of Argentina and Uruguay's supreme courts, in which all of their members resolve all issues as a collegial body. Although they are courts of last resort, the Supreme Court of Mexico and the Federal Supreme Court of Brazil are not included in the analysis because they are clearly oriented towards constitutional justice and therefore lack chambers specialized by subject matter. For these same reasons, I excluded constitutional courts from the analysis. With these refinements, I included 235 members of 14 Latin American supreme courts in the empirical work $(\mathrm{n}=235)$ and coded each one according to gender and the specialized tribunal to which they are assigned.

As shown in Figure 7, an average of $29.37 \%$ of the judges in the specialized chambers with the greatest political impact are female, while $70.63 \%$ are male. Put differently, of the few female judges in the Latin America's supreme courts, only three of ten are in chambers that adjudicate the issues of greatest political significance, such as criminal or constitutional issues. The average is slightly higher for chambers with lower political impact, with female judges accounting for $31.45 \%$ compared to $68.55 \%$ for male judges. Altogether, this empirical

18 Constitutional issues were only considered for countries with supreme courts that have a specialized tribunal for this subject, such as Venezuela or Costa Rica's Tribunal IV. 
finding confirms the previously stated assertion that the unequal representation of women in high courts is not only descriptive or numerical in nature but also found in terms of the roles assigned to them within these tribunals.

Figure 7. Representation of female supreme court judges in terms of political importance of assigned issues

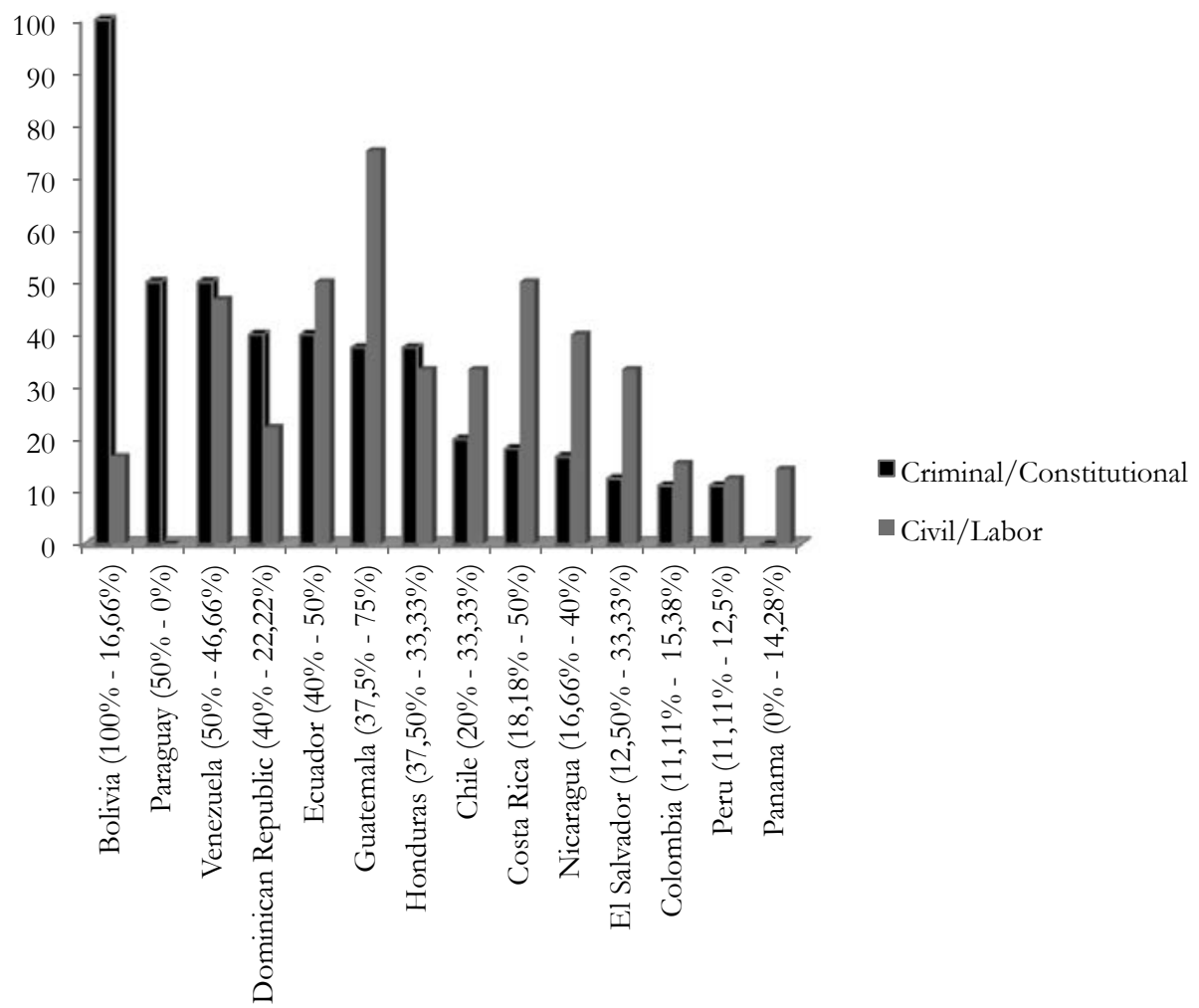

Source: Official websites of Latin American supreme and constitutional courts.

When analyzing the empirical evidence at the country level, emerge at least two patterns of behavior. The first is found in those supreme courts in which the unequal assignment of chambers of high political impact to women is more conspicuous because it is less than one fifth of the total number of benches. Within this group of countries are the supreme courts of Chile (20\%), Costa Rica $(18.18 \%)$, Nicaragua (16.66\%), El Salvador (12.5\%), Colombia $(11.11 \%)$ and Peru $(11.11 \%)$. Panama is the most extreme case, as no women are assigned to the specialized criminal or constitutional chambers of its supreme court. 
The second pattern of behavior is found in countries with supreme courts that have parity or near parity of men and women assigned to chambers addressing high political impact issues. This group includes Paraguay (50\%), Venezuela (50\%), the Dominican Republic (40\%) and Ecuador (40\%). The supreme courts of Guatemala and Honduras $(37.50 \%)$ could also be included, although their level of parity is somewhat lower. Finally, Bolivia is an atypical case because both members of the criminal chamber are women. Despite the fact that the total representation of female judges in Bolivia's supreme court is minor $(33.33 \%)$, they constitute $100 \%$ of the judges addressing issues with the greatest political impact. In fact, no other Latin American country exhibits behavior similar to that observed in Bolivia.

The lack of women making legal decisions in high political impact areas is reaffirmed when evaluating women occupying the presidencies of high courts. In this regard, only $32 \%$ of the supreme or constitutional courts analyzed is chaired by women. When the empirical evidence is disaggregated according to the type of court, the results vary to some extent. In fact, while $38.88 \%$ of supreme courts are presided over by a woman, in the constitutional courts female leadership decreases to $14.28 \%$. Brazil, Colombia, Costa Rica, Guatemala, Nicaragua, Paraguay and Venezuela are the countries that have a woman as president of their supreme courts. For constitutional courts, Colombia is the only country that has a female president among the seven countries with specialized tribunals in this area ${ }^{19}$.

In summary, there is a clearly unequal proportion of female to male judges in both their descriptive representation and the political significance of the issues assigned to female judges in high courts. Although the disproportion has been declining over the last few years in some Latin American countries, the most prominent feature of the region is that at the highest levels of the courts the presence of women is clearly minor. This pattern of inequality occurs in both supreme and constitutional courts and validates that the judiciary is a fruitful area to study the under-representation of women in the political arena.

\section{CONCLUSIONS AND RESEARCH AGENDA}

This article shows the under-representation of women in Latin America's high courts. Although the inequalities between men and women serving in courts are prominent, a noteworthy feature of the research to date is the lack

19 At the beginning of 2018, Ecuador appointed Paulina Aguirre as president of the National Court. 
of focus on this sub field of Political Science. In fact, while studies of the representation of women in legislatures and ministerial cabinets have gained importance during the last several years, studies of female supreme and constitutional judges are candidly marginal. In this regard, this article takes an initial step in the development of a broad research agenda for the analysis of the presence and performance of women in the judicial branch.

On the other hand, this article had showed that there is not a specific pattern in the representation of female legislators, ministers and supreme or constitutional judges. In some countries there is low percentage of women legislators, ministers and judges (Costa Rica, Uruguay or Brazil) but in others there are more women judges than deputies (Venezuela or Guatemala). As a consequence, an interesting question for a future research agenda is related with the variables explaining the similarities or differences mentioned. Additionally, when analyzing the extent to which female judges are assigned to issues of political importance, this article found that the presence of women is minor in the most sought-after criminal and constitutional chambers. This empirical finding is consistent with research of legislatures and ministerial cabinets because in both of these arenas, it was found that women occupy positions with low political impact.

Similarly, this article also found that women serving as presidents of supreme or constitutional courts are rare. Indeed, for at least two reasons, identifying who occupies the presidencies of high courts is a key empirical reference point for observing the distribution of political power within the courts. The first reason is that supreme courts presidents usually assume jurisdiction for adjudicating criminal proceedings against presidents, ministers and other high officials. The second reason is that the office of president of the supreme courts is responsible for both the administrative and fiscal management of the judicial branch. Therefore, the absence of women in this area becomes another empirical reference reinforcing the notion that the exclusion of women in Latin American high courts is a political phenomenon worthy of greater attention.

Additionally, this article's description of the high courts with respect to the age, academic training and previous judicial experience of judges is another input for the subsequent design of research projects that attempt to establish causal links between the under-representation of female judges and other variables. Undertaking a study of this magnitude before having a basic description of the phenomenon studied could lead to spurious explanations or to the over- or under-representation of the causal effects of the analysis variables. Although studies of legislatures and ministerial cabinets have progressed further with possible explanations of the under-representation of women, the nature of the judicial branch merits an independent theoretical framework 
that considers this branch's special characteristics (Basabe-Serrano, 2017). The diversity of selection mechanisms is one of the judgment elements to consider when developing a conceptual design to identify the factors that cause the low representation of women in high courts.

Respect to the future research agenda, the most important aspect is the movement from the study of the number of women in the judicial branch to the analysis of what female judges actually do to defend their interests (Mansbridge et al., 2010). On that level and using the example of sexual and reproductive right cases, it is crucial to know which female judges do or do not have a gender bias. The initial emphasis for this should be on supreme courts decisions because, given the pyramidal structure of the judiciary, its decisions have a cascading effect on the behavior of judges at other levels. However, this does not imply neglecting the analysis of decisions made in the lower courts, because the majority of the legal decisions concerning women's rights are made at this level. In short, scientific research related to the performance of women in the courts is a fertile and inter disciplinary space and one in which the majority of the theoretical and empirical findings are yet to be discovered.

Finally, the future research agenda should also discuss the feasibility or not of designing institutional mechanisms, similar to those used in the legislative, in order to encourage the increase of women judges in high courts. Indeed, the possibility of establishing quota laws or other mechanisms of positive discrimination could constitute a way to reduce the current asymmetries in the representation of women at the highest levels of the judicial branch. Indeed, the debate is open because, beyond the mentioned effects, it is necessary to discuss to what extent this type of institutional arrangements are appropriate for supreme and constitutional courts, in which the election of its members is not possible.

\section{Bibliography}

Alozie, N. O. (1996). Selection Methods and the Recruitment of Women to State Courts of Last Resorts. Social Science Quarterly, 77, 110-126.

Amorin-Neto, O. (2002). Presidential Cabinets, Electoral Cycles, and Coalition Discipline in Brazil. In S. Morgenstern and B. Nacif (eds.). Legislative Politics in Latin America (pp. 48-78). Cambridge: Cambridge University Press. Available at: https://doi. org/10.1017/CBO9780511615665.004.

Baldez, L. (2002). Why Women Protest: Women's Movements in Chile. Cambridge: Cambridge University Press. Available at: https://doi.org/10.1017/CBO9780511756283.

Basabe-Serrano, S. (2017). Las desigualdades en la representación de mujeres en cortes supremas de América Latina. In S. Blanke and S. Kurtenbach (coords.). Violencia y Desigualdad (pp. 220-234). Buenos Aires: Nueva Sociedad; Friederich Eber Stiftung. 
(2019). La sub-representación de mujeres en gabinetes ministeriales: el caso ecuatoriano en perspectiva comparada, 1979-2015. Latin American Research Review, 1-34. (forthcoming).

Bego, I. (2014). Accessing Power in New Democracies: The Appointment of Female Ministers in Postcommunist Europe. Political Research Quarterly, 67 (2), 347-360. Available at: https://doi.org/10.1177/1065912913509028.

Bensouda, F. (2014). Gender Justice and the ICC. International Feminist Journal of Politics, 16 (4), 538-542. Available at: https://doi.org/10.1080/14616742.2014.952125.

Borner, J., Caminotti, M., Marx, J. and Rodríguez Gustá, A. L. (2009). Ideas, presencia y jerarquías políticas. Buenos Aires: Prometeo; Programa de las Naciones Unidas para el Desarrollo.

Bratton, K. A. and Spill, R. L. (2002). Existing Diversity and Judicial Selection: The Role of the Appointment Method in Establishing Gender Diversity in State Supreme Courts. Social Science Quarterly, 83, 504-518. Available at: https://doi.org/10.1111/15406237.00097.

Caul, M. (2001). Political Parties and the Adoption of Candidate Gender Quotas: A Cross-National Analysis. Journal of Politics, 63 (4), 1214-1229. Available at: https://doi. org/10.1111/0022-3816.00107.

Cowan, R. B. (2006). Women's Representation on the Courts in the Republic of South Africa. University of Maryland Law Journal on Race, Religion, Gender and Class, 6, 291-318.

Davis, R. H. (1997). Women and Power in Parliamentary Democracies: Cabinet Appointments in Western Europe, 1968-1992. Lincoln: University of Nebraska Press.

Durbach, A. and Chappell, L. (2014). Leaving Behind the Age of Impunity. International Feminist Journal of Politics, 16 (4), 543-562. Available at: https://doi.org/10.1080/1461 6742.2014.941251.

Escobar-Lemmon, M. and Taylor-Robinson, M. M. (2005). Women Ministers in Latin American Government: When, Where and Why? American Journal of Political Science, 49 (4), 829-844. Available at: https://doi.org/10.1111/j.1540-5907.2005.00158.x.

Fallon, M. K., Beckfield, J. and Viterna, J. (2008). How Development Matters: A Research Note on the Relationship between Development, Democracy and Women's Political Representation. International Journal of Comparative Sociology, 49 (6), 455-477. Available at: https://doi.org/10.1177/0020715208097789.

Fleischer, J. and Seyfried, M. (2015). Drawing from the Bargaining Pool: Determinants of the Ministerial Selection in Germany. Party Politics, 21 (4), 503-514. Available at: https:// doi.org/10.1177/1354068813487108.

García Montero, M. (2007). La actividad legislativa en América Latina: sobre el papel reactivo y proactivo de los presidentes y parlamentos. Lateinamerika Analyzen, 17, 3-22.

Grey, R. (2014). Sexual Violence against Child Soldiers. International Feminist Journal of Politics, 16 (4), 601-621. Available at: https://doi.org/10.1080/14616742.2014.955964.

Heppell, T. (2012). Ministerial Selection and the Cameron Government: Female Ministerial Representation and the One-Third Objective. Representation, 48 (2), 209-219. Available at: https://doi.org/10.1080/00344893.2012.683492.

Hoekstra, V. (2010). Increasing the Gender Diversity of High Courts: A Comparative View. Politics and Gender, 6 (3), 474-484. Available at: https://doi.org/10.1017/S17439 23X10000243. 
Htun, M. N. (2003). Women and Democracy. In J. I. Domínguez and M. Schifter (eds.). Constructing Democratic Governance in Latin America. Baltimore: John Hopkins University Press.

— and Jones, M. P. (2001). Engendering the Right to Participate in Decision-making: Electoral Quotas and Women's Leadership in Latin America. In N. Craske and M. Molyneux (eds.). Gender and the Politics of Rights and Democracy in Latin America (pp. 32-56). London: Palgrave. Available at: https://doi.org/10.1057/9781403914118_2.

— and Piscopo, J. (2014). Women and Politics in Policy in Latin America and the Caribbean. Working Paper Social Science Research Council, 2.

Hurwitz, M. S. and Lanier, D. N. (2003). Explaining Judicial Diversity: The Differential Ability of Women and Minorities to Attain Seats of State Supreme and Appellate Courts. State Politics and Policy Quarterly, 3 (4), 329-352. Available at: https://doi. org/10.1177/153244000300300401.

Inglehart, R. and Norris, P. (2003). Rising Tide: Gender Equality and Cultural Change around the World. Cambridge: Cambridge University Press. Available at: https://doi. org/10.1017/CBO9780511550362.

Jalalzai, F. (2014). Gender, Presidencies, and Prime Ministerships in Europe: Are Women Graining Ground? International Political Science Review, 35 (5), 577-594. Available at: https://doi.org/10.1177/0192512114542112.

Jones, M. P. (2004). Quota Legislation and the election Gender Quotas, Electoral Laws, and the Election of Women: Learning from the Costa Rican Experience. Journal of Politics, 66 (4), 1203-1223. Available at: https://doi.org/10.1111/j.0022-3816.2004.00296.x.

- (2009). Gender Quotas, Electoral Laws, and the Election of Women: Evidence from Latin American Vanguard. Comparative Political Studies, 42 (1), 56-81. Available at: https://doi.org/10.1177/0010414008324993.

— , Alles, S. and Tchintian, C. (2012). Cuotas de género, leyes electorales y elección de legisladoras en América Latina. Revista de Ciencia Politica, 32 (2), 331-357. Available at: https://doi.org/10.4067/S0718-090X2012000200001.

Kenney, S. J. (2002). Breaking the Silence: Gender Mainstreaming and the Composition of the European Court of Justice. Feminist Legal Studies, 10 (3), 257-270. Available at: https://doi.org/10.1023/A:1021227929264.

- (2010). Critical Perspectives on Gender and Judging. Politics and Gender, 6 (3), 433441. Available at: https://doi.org/10.1017/S1743923X10000310.

Kobayashi, Y. (2004). Has the Closed Door Opened for Women? The Appointment of Women ministers in Japan. Political Science and Politics, 37 (1), 63-64.

Koomen, J. (2014). Language Work at International Criminal Courts. International Feminist Journal of Politics, 16 (4), 581-600. Available at: https://doi.org/10.1080/14616742.20 14.947732.

Krook, M. L. and O'Brien, D. Z. (2012). All the President's Men? The Appointment of Female Cabinet Ministers Worldwide. Journal of Politics, 74 (3), 840-855. Available at: https://doi.org/10.1017/S0022381612000382.

Kunovich, S. and Paxton, P. (2005). Pathways to Power: The Role of Political Parties in Women's National Political Representation. American Journal of Sociology, 111 (2), 505-552. Available at: https://doi.org/10.1086/444445. 
Lovenduski, J. and Norris, P. (1993). Gender and Party Politics. London: SAGE.

Malleson, K. (2003). Justifying Gender Equality on the Bench: What Difference Won't Do. FeministLegalStudies,11(1),1-24.Availableat:https://doi.org/10.1023/A:1023231006909.

Malleson, K. (2009). Diversity in the Judiciary: The Case for the Positive Action. Journal of Law and Society, 36 (3), 376-402. Available at: https://doi.org/10.1111/j.14676478.2009.00472.x.

Mansbridge, J. (1990a). Beyond Adversary Democracy. Chicago: University of Chicago Press.

- (1990b). Feminism and Democracy. The American Prospect, 1, 127.

- (1994). Feminism and Democratic Community. In S. M. Okin and J. Mansbridge. Feminism (School of Thought in Politics). New York: Edward Elgar Pub.

— , Bohman, J., Chambers, S., Estlund, D., Follesdal, A., Fung, A., Lafont, C., Manin, B. and Martí, J. L. (2010). The Place of Self-Interest and the role of Power in Deliberative Democracy. Journal of Political Philosophy, 18 (1), 64-100. Available at: https://doi. org/10.1111/j.1467-9760.2009.00344.x.

Marion, P. (2007). La parité dés-enchantée. Travail, Gender et Societies, 18 (2), 153-156. Available at: https://doi.org/10.3917/tgs.018.0153.

Matland, R. E. (1998). Women's Representation in National Legislatures: Developed and developing Countries. Legislative Studies Quarterly, 23 (1), 109-125. Available at: https://doi.org/10.2307/440217.

— and Studlar, D. T. (1996). The Contagion of Women Candidates in Single-Member District and Proportional Representation Systems: Canada and Norway. Journal of Politics, 58 (3), 707-733. Available at: https://doi.org/10.2307/2960439.

Maveety, N. (2010). Difference in Judicial Discourse. Politics and Gender, 6 (3), 452-465. Available at: https://doi.org/10.1017/S1743923X10000255.

Ní Aoláin, F. (2014). Gendered Harms and their Interface with International Criminal Law. International Feminist Journal of Politics, 16 (4), 622-646. Available at: https://doi.org/ 10.1080/14616742.2014.952126.

Norris, P. (1987). Politics and Sexual Equality: The Comparative Position of Women in Western Democracies. Boulder: Rienner.

- (1997). Introduction: Theories of Recruitment. In P. Norris (ed.). Passages to Power: Legislative Recruitment in Advanced Democracies (pp. 1-14). Cambridge: Cambridge University Press.

— and Lovenduski, J. (1995). Political Recruitment. New York: Cambridge University Press. Available at: https://doi.org/10.1017/CBO9780511598609.

Oosterverld, V. (2014). Constructive Ambiguity and the Meaning of "Gender" for the International Criminal Court. International Feminist Journal of Politics, 16 (4), 563-580. Available at: https://doi.org/10.1080/14616742.2014.950818.

Pateman, C. (1970). Participation and Democratic Theory. Cambridge: Cambridge University Press. Available at: https://doi.org/10.1017/CBO9780511720444.

Paxton, P. and Kuvonich, S. (2003). Women's Political Representation: The Importance of Ideology. Social Forces, 81 (2), 87-114. Available at: https://doi.org/10.1353/sof.2003.0105.

Phillips, A. (1991). Engendering Democracy. Cambridge: Polity Press.

Reid, T. V. (2004). Assessing the Impact of a Candidate's Sex in Judicial Campaigns and Elections in North Carolina. Justice System Journal, 25 (2), 183-207. 
- (2010). Women Candidates and Judicial Elections: Telling an Untold Story. Politics and Gender, 6 (3), 465-474. Available at: https://doi.org/10.1017/S1743923X10000267.

Reynolds, A. (1999). Women in the Legislatures and Executives on the World: Knocking at the Highest Glass Ceiling. World Politics, 51 (4), 547-572. Available at: https://doi. org/10.1017/S0043887100009254.

Rodríguez, V. E. (2003). Women in Contemporary Mexican Politics. Austin: University of Texas Press.

Russell, C. A. and Delancey, M. W. (2002). African Women in Cabinet Positions - Too Few Too Weak. Asian Women, 15 (2), 147-163.

Sainsbury, D. (2004). Women's Political Representation in Sweden: Discursive Politics and Institutional Presence. Scandinavian Political Studies, 27 (1), 65-87. Available at: https:// doi.org/10.1111/j.0080-6757.2004.100_1.x.

Scribner, D. and Lambert, P. A. (2010). Constitutionalizing Difference: A Case Study Analysis of Gender Provisions in Botswana and South Africa. Politics and Gender, 6 (1), 37-61. Available at: https://doi.org/10.1017/S1743923X0999050X.

Shen, A. (2017). Women Judges in Contemporary China. New York: Palgrave Macmillan. Available at: https://doi.org/10.1007/978-3-319-57840-8.

Siaroff, A. (2000). Women's Representation in Legislatures and Cabinets in Industrial Democracies. International Political Science Review, 21 (2), 197-215. Available at: https://doi. org/10.1177/0192512100212005.

Skjeie, H. (1991). The Rhetoric of Difference: On Women's Inclusion into Political Elites. Politics and Society, 19 (2), 233-263. Available at: https://doi.org/10.1177/003232929101900205.

Studlar, D. T. and Matland, R. E. (1996). The Dynamics of Women's Representation in the Canadian Provinces, 1975-1994. Canadian Journal of Political Science, 29 (2), 269-293. Available at: https://doi.org/10.1017/S000842390000771X.

Studlar, D. T. and Moncrief, G. F. (1997). The Recruitment of Women Cabinet Ministers in the Canadian Provinces. Governance, 10 (1), 67-81. Available at: https://doi. org/10.1111/0952-1895.291996029.

- (1999). Women's Works? The Distribution and Prestige of Portfolios in the Canadian Provinces. Governance, 12 (4), 379-395. Available at: https://doi.org/10.1111/09521895.00110.

Szmer, J. J., Tammy, A. S. and Erin, B. K. (2010). Have We Come a Long Way, Baby? The Influence of Attorney Gender on Supreme Court Decision Making. Politics and Gender, 6 (1), 1-36. Available at: https://doi.org/10.1017/S1743923X09990493.

True, J. and Mintrom, M. (2001). Transnational Networks and policy Diffusion: The Case of Gender Mainstreaming. International Studies Quarterly, 45 (1), 27-57. Available at: https://doi.org/10.1111/0020-8833.00181.

Welzel, C., Pippa, N. and Inglehart, R. (2002). Gender Equality and Democracy. Comparative Sociology, 1(3-4),321-345.Availableat:https://doi.org/10.1163/156913302100418628.

Whitford, A. B., Wilkins, V. M. and Ball, M. G. (2007). Descriptive Representation and Policy-making Authority: Evidence from Women in Cabinets and Bureaucracies. Governance, 20 (4), 559-580. Available at: https://doi.org/10.1111/j.14680491.2007.00372.x. 
Williams, M. S. 2007. Women Judges: Accession at the State Court Level. Social Science Quarterly, 88 (5), 1192-1204. Available at: https://doi.org/10.1111/j.1540-6237.2007.00498.x.

— and Thames, F. C. 2008. Women's Representation on High Courts in Advanced Industrialized Countries. Politics and Gender, 4 (3), 451-471. Available at: https://doi. org/10.1017/S1743923X08000366.

\section{Appendix}

Appendix 1. Descriptive statistics: judges in high courts of latin america, 2017

\begin{tabular}{lccccc}
\hline Variable & $\begin{array}{c}\text { Number of } \\
\text { observations }\end{array}$ & Min & Max & Media & $\begin{array}{c}\text { Standar } \\
\text { desviation }\end{array}$ \\
\hline Sex* & 326 & 0 & 1 & .31 & .462 \\
\hline Court* & 326 & 1 & 2 & 1.18 & .388 \\
\hline Education** $^{*}$ & 324 & 1 & 3 & 1.86 & .798 \\
\hline Experience* $^{*}$ & 326 & 0 & 1 & .60 & .490 \\
\hline
\end{tabular}

* Sex, court and experience in judicial branch are dummy variables: woman/man, supreme/constitutional, and, judges with previous judicial experience/judges without previous judicial experience.

** Education was observed in three categories: bachelor, master and $\mathrm{PhD}$ degrees.

Appendix 2. Correlation of sex and education in latin american high courts

\begin{tabular}{llcc}
\hline & & Sex & Education \\
\hline \multirow{5}{*}{ Gender } & Pearson correlation & 1 & -.057 \\
\cline { 2 - 4 } & Sig. (bilateral) & & .306 \\
\cline { 2 - 4 } & Sum of squares and cross products & 68.656 & -6.641 \\
\cline { 2 - 4 } & Covariance & .213 & -.021 \\
\cline { 2 - 4 } & $\mathrm{N}$ & 323 & 323 \\
\hline \multirow{5}{*}{ Education } & Pearson correlation & -.057 & 1 \\
\cline { 2 - 4 } & Sig. (bilateral) & .306 & .612 \\
\cline { 2 - 4 } & Sum of squares and cross products & -6.641 & 197.102 \\
\cline { 2 - 4 } & Covariance & -.021 & 323 \\
\cline { 2 - 4 } & $\mathrm{N}$ & 323 & .612 \\
\hline
\end{tabular}

